\title{
Photodegradation Products of Tetrachlorodibenzo-p-dioxins under Xenon Lamp Irradiation
}

\author{
Masaji Koshioka, Tadao Yamada, Jun Kanazawa \\ and Toshinobu MURAI \\ National Institute of Agro-Environmental Sciences, Kannondai, Tsukuba 305, Japan
}

(Received September 8, 1988)

\begin{abstract}
The photodegradation of 2,3,7,8-tetrachlorodibenzo-p-dioxin (2,3,7,8-TCDD), 1,3,6,8TCDD and 1,2,3,4-TCDD in 1,4-dioxane solutions was studied under xenon lamp irradiation. Only reductive dechlorination reaction was observed in the photodegradation of TCDDs. $2,3,7$-Trichlorodibenzo- $p$-dioxin $\quad(2,3,7-\operatorname{TrCDD}), 2,7$-dichlorodibenzo- $p$-dioxin $\quad(2,7$-DCDD), 2,8-DCDD, 2-monochlorodibenzo- $p$-dioxin (2-MCDD) and dibenzo- $p$-dioxin (DD) were identified as the photodegradation products by GC-MS in the photodegradation of 2,3,7,8-TCDD. 1,3,6-TrCDD, 1,3-DCDD, 1,6-DCDD, 1-MCDD, 2-MCDD and DD were identified in the photodegradation of 1,3,6,8-TCDD, while 1,2,3-TrCDD, 1,2,4-TrCDD, 1,2-DCDD, 1,3-DCDD, 1,4DCDD, 2,3-DCDD, 1-MCDD, 2-MCDD and DD in the photodegradation of 1,2,3,4-TCDD. In the photodegradation reaction, chlorine atoms in the 2, 3, 7 and/or 8-positions were dechlorinated more rapidly than those in the 1, 4, 6 and/or 9-positions.
\end{abstract}

\section{INTRODUCTION}

Polychlorinated dibenzo-p-dioxins (PCDDs) have been recognized as by-products of certain chlorinated phenols and the related compounds. ${ }^{1)} \quad$ Among chlorinated dioxins, 2,3,7,8tetrachlorodibenzo- $p$-dioxin $(2,3,7,8$-TCDD) is the most toxic, teratogenic, and acnegenic. ${ }^{1,2)}$

2,3,7,8-TCDD in methanol solutions easily photodegrades under sunlight or on kieselguhr under ultraviolet light. ${ }^{3,4}$ Although reductive dechlorination reaction is shown as a major photodegradation pathway of a number of $\mathrm{PCDDs}^{5-10)}$ as well as polychlorinated aromatic compounds, ${ }^{11-14)}$ photodegradation products and photodegradation pathways of TCDDs have not been clearly clarified yet.

In the present study we investigate photodegradation products of 2,3,7,8-TCDD, 1,3,6,8TCDD and 1,2,3,4-TCDD, and their possible photodegradation pathways in 1,4-dioxane solutions under xenon lamp irradiation.

\section{MATERIALS AND METHODS}

Test compounds 2,3,7,8-TCDD and 1,2,3,4TCDD were purchased from Cambridge Isotope Laboratories and Gasukuro Kogyo Co. Ltd., respectively. Another test compound 1,3,6,8TCDD was a gift from Mitsui-Toatsu Chemical Inc. Other standard compounds 1,2,4-trichlorodibenzo-p-dioxin (1,2,4-TrCDD), 1,6dichlorodibenzo- $p$-dioxin (1,6-DCDD), 2,3DCDD, 2,7-DCDD, 1-monochlorodibenzo- $p$ dioxin (1-MCDD), 2-MCDD and dibenzo- $p$ dioxin (DD) were also purchased from Gasukuro Kogyo Co. Ltd.

TCDDs were dissolved in 1,4-dioxane to make 1-ppm solutions. A 3-ml aliquot of each solution was taken into a cubic quartz cell $(1 \times 1 \times 5 \mathrm{~cm})$, and irradiated at a wavelength of $252.6 \mathrm{~nm}$ with a JASCO CRM-FA xenon lamp irradiator. After irradiated for $16.7 \mathrm{~min}$ to $266.7 \mathrm{~min}, 1 \mu \mathrm{l}$ of each solution was subjected to GC-MS for the analysis of photodegradation products. 


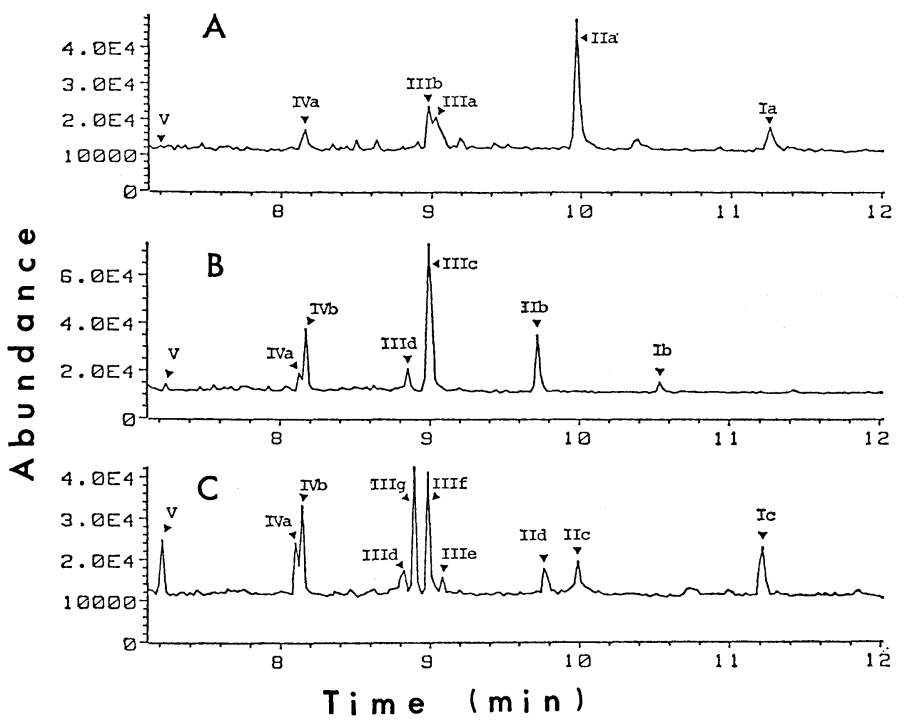

Fig. 1 Total ion chromatograms of photodegradation products of tetrachlorodibenzo- $p$ dioxins (TCDDs) formed under xenon lamp irradiation.

Three kinds of TCDDs in 1,4-dioxane solutions were irradiated at $252.6 \mathrm{~nm}$ for $266.7 \mathrm{~min}$. A: 2,3,7,8-TCDD, B: 1,3,6,8-TCDD, C: 1,2,3,4-TCDD, I: tetrachlorodibenzo-p-dioxins, II: trichlorodibenzo-p-dioxins, III: dichlorodibenzo-p-dioxins, IV: monochlorodibenzo- $p$-dioxins, $\mathbf{V}$ : dibenzo-p-dioxin.

A Hewlett Packard 5890 GC equipped with a splitless injector and a 5970B series mass selective detector were used with a cross-linked methylsilicone capillary column (25 m length, $0.33 \mu \mathrm{m}$ film thickness, $0.2 \mathrm{~mm}$ i.d.). Conditions: head pressure, $1056 \mathrm{~g} / \mathrm{cm}^{2}$; carrier gas, $\mathrm{He}$; EM volts, $1800-2400$; initial temp., $60^{\circ} \mathrm{C}$; initial time, $1 \mathrm{~min}$; final temp., $250^{\circ} \mathrm{C}$; program rate, $25^{\circ} \mathrm{C} / \mathrm{min}$; interface temp., $270^{\circ} \mathrm{C}$; injection temp., $250^{\circ} \mathrm{C}$.

\section{RESULTS AND DISCUSSION}

In most cases polychlorinated aromatic compounds easily lost their chlorine atoms photochemically. The parent structure may be dechlorinated either via dissociation of an excited molecule to a free radical or via nucleophilic displacement reaction. ${ }^{15)}$ As expected, reductive dechlorination reaction was observed in the photodegradation of TCDDs. The capillary GC chromatograms of TCDDs in 1-ppm 1,4-dioxane solutions after 266.7-min irradiation at $252.6 \mathrm{~nm}$ showed the formation of less chlorinated dioxins and unchlorinated dioxins (Fig. 1). No other photodegradation products were formed via nucleophilic displacements, ring hydration or ring fission.

In the photodegradation products of 2,3,7,8TCDD, one possible isomer of $\operatorname{TrCDD}$, two of the three possible isomers of DCDD, one possible isomer of MCDD and DD were observed (Fig. 1A). Compounds Ia, IIIb, IVa and V were identified as 2,3,7,8-TCDD (the parent), 2,7-DCDD, 2-MCDD and DD, respectively, by GC-MS based on cochromatography with the authentic compounds (Table 1 and Fig. 2). Compound IIa was identified as 2,3,7-TrCDD, because the compound was the only one possible trichlorinated dioxin originated from 2,3,7, 8-TCDD. Compound IIIa was speculated as 2,8-DCDD, because its retention time did not correspond to the retention times of other two possible isomers, 2,3-DCDD and 2,7-DCDD.

In the photodegradation products of $1,3,6,8-$ TCDD, one of the two possible isomers of TrCDD, two of the four possible isomers of DCDD, all two possible isomers of MCDD, and DD were observed (Fig. 1B). Compounds Ib, IIIc, IVa, IVb and $\mathbf{V}$ were identified as $1,3,6,8$ TCDD (the parent), 1,6-DCDD, 2-MCDD, 1- 
Table 1 Identification and recovery ratios of parental TCDD and their photodegradation products in a 1-ppm 1,4-dioxane solution after 200min of xenon lamp irradiation at a wavelength of $252.6 \mathrm{~nm}$.

\begin{tabular}{lrrl}
\hline $\begin{array}{c}\text { Compound } \\
\text { (Fig. 1) }\end{array}$ & $\begin{array}{r}\text { Retention } \\
\text { time } \\
\text { (min) }\end{array}$ & $\begin{array}{r}\text { Recovery } \\
\text { ratio }\end{array}$ & \multicolumn{1}{c}{ Identity } \\
\hline Ia & 11.26 & 0.107 & $2,3,7,8-\mathrm{TCDD}$ \\
IIa & 9.99 & 0.308 & $2,3,7-\mathrm{TrCDD}$ \\
IIIa & 8.01 & 0.063 & $2,8-\mathrm{DCDD}$ \\
IIIb & 8.98 & 0.116 & $2,7-\mathrm{DCDD}$ \\
IVa & 8.11 & 0.046 & $2-\mathrm{MCDD}$ \\
V & 7.22 & 0.018 & DD \\
\hline Ib & 10.51 & 0.079 & $1,3,6,8-\mathrm{TCDD}$ \\
IIb & 9.70 & 0.471 & $1,3,6-\mathrm{TrCDD}$ \\
IIIc & 8.99 & 1.099 & $1,6-\mathrm{DCDD}$ \\
IIId & 8.83 & 0.118 & $1,3-\mathrm{DCDD}$ \\
IVb & 8.15 & 0.217 & $1-\mathrm{MCDD}$ \\
IVa & 8.11 & 0.128 & $2-\mathrm{MCDD}$ \\
V & 7.22 & 0.135 & DD \\
\hline Ic & 11.21 & 0.028 & $1,2,3,4-\mathrm{TCDD}$ \\
IIc & 10.01 & 0.015 & $1,2,3-\mathrm{TrCDD}$ \\
IId & 9.79 & 0.015 & $1,2,4-\mathrm{TrCDD}$ \\
IIIe & 9.08 & 0.012 & $1,2-/ 1,4-\mathrm{DCDD}$ \\
IIIf & 8.98 & 0.052 & $2,3-\mathrm{DCDD}$ \\
IIIg & 8.89 & 0.049 & $1,2-/ 1,4-\mathrm{DCDD}$ \\
IIId & 8.83 & 0.018 & $1,3-\mathrm{DCDD}$ \\
IVb & 8.15 & 0.043 & $1-\mathrm{MCDD}$ \\
IVa & 8.11 & 0.030 & $2-\mathrm{MCDD}$ \\
V & 7.22 & 0.029 & DD \\
\hline
\end{tabular}

a) The recovery ratios are shown as relative intensities to each unirradiated parent TCDD.

MCDD and DD, respectively, by GC-MS based on cochromatography with the authentic compounds (Table 1 and Fig. 2). The mass spectrum of compound IIId corresponded to that of dichlorinated dioxin so that compound IIId would be one of the four possible dichlorinated products, that is, either 1,2-DCDD, 1,3-DCDD, 1,4-DCDD or 2,3-DCDD, originated from 1,2,3,4-TCDD. Since 1,3-DCDD was the only one common isomer of dichlorinated dioxins produced from both 1,3,6,8-TCDD and 1,2,3,4-TCDD, compound IIId was tentatively identified as 1,3-DCDD. Compound IIb was speculated as $1,3,6-\operatorname{TrCDD}$, because the identified 1,3-DCDD and 1,6-DCDD seemed to be originated from 1,3,6-TrCDD, and 1,8-


Mass / Charge

Fig. 2 Mass spectra of tetrachlorodibenzo- $p$ dioxin and its photodegradation products formed under xenon lamp irradiation.

I: tetrachlorodibenzo-p-dioxin, II: trichlorodibenzo- $p$-dioxin, III: dichlorodibenzo- $p$-dioxin, IV: monochlorodibenzo- $p$-dioxin, $\mathbf{V}$ : dibenzo- $p$-dioxin.

DCDD, which is originated from 1,3,8-TrCDD, was not observed.

In the photodegradation products of $1,2,3,4$ TCDD, all two possible isomers of TrCDD, all four possible isomers of DCDD, all two possible isomers of MCDD and DD were observed (Fig. 1C). Compounds Ic, IId, IIIf, IVa, IVb and V were identified as 1,2,3,4-TCDD (the parent), 1,2,4-TrCDD, 2,3-DCDD, 2-MCDD, I-MCDD and $\mathrm{DD}$, respectively, by GC-MS based on cochromatography with authentic compounds (Table 1 and Fig. 2). Compound IIc was tentatively identified as the other possible trichlorinated product 1,2,3-TrCDD. Compound IIId showed the same retention time and mass spectrum as those of dichlorinated dioxin 1,3-DCDD formed in the photodegradation of 1,3,6,8-TCDD. Each of compounds IIIg and IIIe was supposed to be one of the possible dichlorinated products 1,2-DCDD and 1,4- 


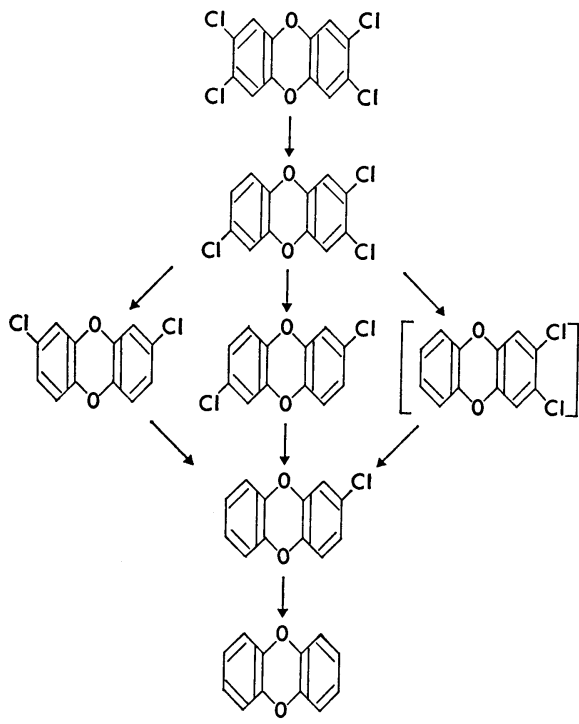

Fig. 3 Proposed photodegradation pathways of $2,3,7,8$-tetrachlorodibenzo- $p$-dioxin in 1,4-dioxane solutions under xenon lamp irradiation.

The compound in blacket was not observed in the experiment.

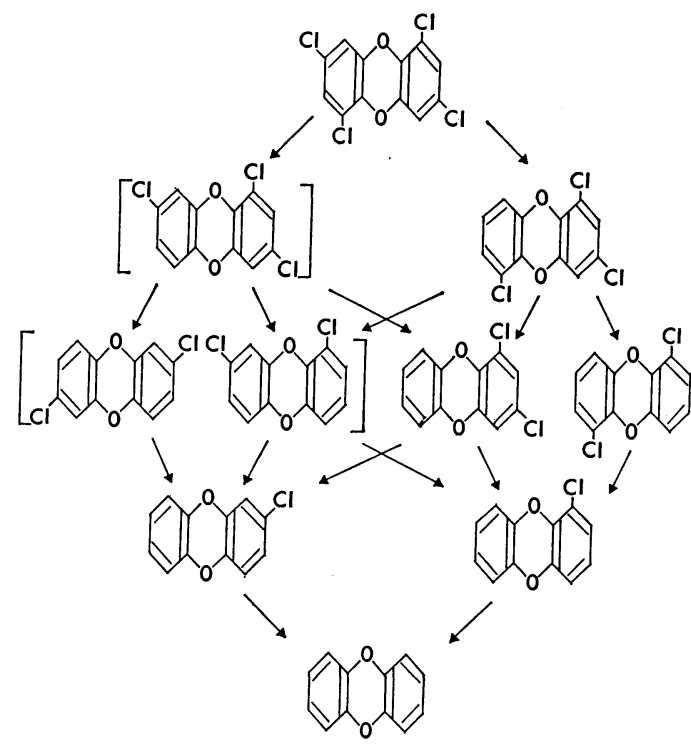

Fig. 4 Proposed photodegradation pathways of 1,3,6,8-tetrachlorodibenzo-p-dioxin in 1,4-dioxane solutions under xenon lamp irradiation.

The compounds in blacket were not observed in the experiment.

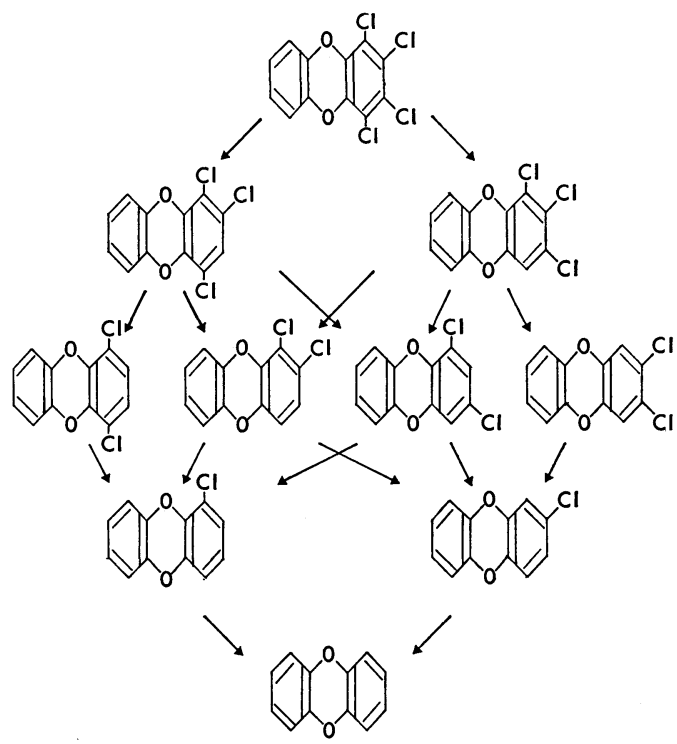

Fig. 5 Proposed photodegradation pathways of $1,2,3,4$-tetrachlorodibenzo- $p$-dioxin in 1,4-dioxane solutions under xenon lamp irradiation.

\section{DCDD.}

As shown in Table 1 , the formation ratio of 1,6-DCDD was relatively higher than that of 1,3-DCDD with the formation ratio of 1MCDD than that of 2-MCDD when 1,3,6,8TCDD photodegraded. The formation ratio of 1-MCDD was also higher than that of 2-MCDD when 1,2,3,4-TCDD photodegraded. Since the apparent preferential loss of chlorine atoms at the 2, 3, 7 and/or 8-positions has been observed when highly chlorinated dioxins photodegraded, ${ }^{5,16)}$ the above results and the apparent absence of 1,3,8-TrCDD, 2,7-DCDD and 1,8-DCDD in the photodegradation of $1,3,6,8-T C D D$ suggest that chlorinated dioxins with chlorine atoms at the 2, 3, 7 and/or 8positions also undergo photodegradation more rapidly than those with chlorine atoms at the $1,4,6$ and/or 9-positions in the photodegradation of less chlorinated dioxins.

Possible photodegradation pathways of 2,3, 7,8-TCDD, 1,3,6,8-TCDD, and 1,2,3,4-TCDD in 1,4-dioxane solutions are shown in Figs. 3, 4 and 5 , respectively.

\section{ACKNOWLEDGMENTS}

We acknowledge with thanks the authentic 1,3,6,8- 
TCDD received from Mitsui-Toatsu Chemical Inc. This research was partially supported by a grant for Environment Preservation Research from the Environment Agency of Japan.

\section{REFERENCES}

1) H. Bauer, K. H. Schultz \& U. Spiegelberg: Arch. Gewerbepathol. Gewerbehyg. 18, 538 (1961)

2) C. R. Higginbotham, A. Huang, D. Firestone, J. Verrett, J. Ross \& A. D. Campbell: Nature 220, 702 (1968)

3) D. C. Crosby, A. S. Wong, J. R. Plimmer \& E. A. Woolson: Science 173, 748 (1971)

4) I. Gebefugi, R. Baumann \& F. Korte: Naturwissenschaften 64, 486 (1977)

5) H. R. Buser: J. Chromatogr. 129, 303 (1976)

6) A. J. Dobbs \& C. Grant: Nature 278, 163 (1979)

7) T. J. Nestrick \& L. L. Lamparski: Anal. Chem. 50, 1865 (1980)

8) G. G. Choudhry \& G. R. B. Webster: Chemosphere 14, 9 (1985)

9) G. G. Choudhry \& G. R. B. Webster: Chemosphere 15, 1935 (1986)

10) G. C. Miller, V. R. Hebert, M. J. Miille, R. Mitzel \& R. G. Zepp: The 7th International Symposium on Chlorinated Dioxins and Related Compounds, Abstract TF06 (1987)

11) M. Koshioka, H. Iizuka, J. Kanazawa \& T. Murai: Agric. Biol. Chem. 51, 949 (1987)

12) M. Koshioka, J. Kanazawa, H. Iizuka \& T. Murai: Bull. Environ. Contam. Toxicol. 38, 409 (1987)
13) M. Koshioka, T. Suzuki, J. Kanazawa \& T. Murai: J. Pesticide Sci. 12, 229 (1987)

14) M. Koshioka, H. Iizuka, J. Kanazawa, T. Suzuki, T. Yamada, T. Masuda \& T. Murai: J. Pesticide Sci. 12, 447 (1987)

15) J. R. Plimmer, U. I. Klingebiel, D. G. Crosby \& A. S. Wong: Adv. Chem. Ser. No. 120, 44 (1973)

16) H. R. Buser: Chemosphere 8, 251 (1979)

要 約

\section{キセノンランプ光照射によるテトラクロロダイ オキシン類の光分解物}

腰岡政二，山田忠男，金沢 純，村井敏信

ジオキサン溶液中のテトラクロロダイオキシン (TCDD) 類の光分解反応は還元的脱塩素反応であり, $2,3,7,8$-TCDD の光分解生成物として $2,3,7$-トリクロ

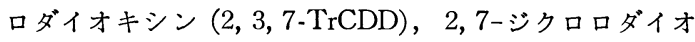
キシン (2,7-DCDD)，2,8-DCDD，2-モノクロロダイオ キシン (2-MCDD) およびダイベンゾダイオキシン (DD) が，また $1,3,6,8$-TCDD の光分解生成物として $1,3,6$ TrCDD, 1, 3-DCDD, 1, 6-DCDD, 1-MCDD, 2-MCDD および $\mathrm{DD}$ が，そして 1,2,3,4-TCDD の光分解生成物 として 1, 2, 3-TrCDD, 1, 2, 4-TrCDD, 1, 2-DCDD, 1, 3DCDD, 1, 4-DCDD, 2, 3-DCDD, 1-MCDD, 2-MCDD および DD が GC-MS で同定された。還元的脱塩素反応 は，主として 2 位， 3 位， 7 位あるいは 8 位の炭素に結 合している塩素から優先的に起こるものと推定された。 